https://doi.org/10.17816/MAJ191S1211-212

\title{
EFFECTS OF KARMIZOLE DERIVATE ON THE EXPRESSION OF APO A-I GENE IN THE RAT'S HYPERLIPIDEMIA MODEL
}

\author{
A.V. Lizunov, I.V. Okunevich, P.D. Shabanov
}

Department of Neuropharmacology, Institute of the Experimental Medicine, Saint Petersburg, Russia

\section{ВЛИЯНИЕ ПРОИЗВОДНОГО КАРМИЗОЛА НА ЭКСПРЕССИЮ ГЕНА АПОЛИПОПРОТЕИНА А1 В МОДЕЛИ ЭКСПЕРИМЕНТАЛЬНО ИНДУЦИРОВАННОЙ ГИПЕРЛИПИДЕМИИ КРЫС}

\author{
А.В. Лизунов, И.В. Окуневич, П.Д. Шабанов
}

ФГБНУ «Институт экспериментальной медицины», отдел нейрофармакологии, Санкт-Петербург

Azoles are the main antifungal drug class. The main mechanism of the azoles action is the intercalation in the sterol biosynthesis regulation. At the same time, the effect of the azole derivates on mammals is antiatherogenic. But there were no publication about connection between azole derivates effect on hyperlipidemia and expression of genes with antiatherogenic effects.

In our work we used triton model of hyperlipodemia on rats to analyze the effect of carmizole injection on the expression of the main antiatherogenic genes and their regulators Apo A-I, HDL, LDL.

We had four groups of rats: intact control group, triton control group, phenophibrate group and carmizole group. During a seven days we gave a per oral injections of carmizole for the carmizole group, phenophibrate (as a comparison drug) for phenophibrate group and 1\% starch solution for triton control group. Liver tissue samples were used for RNA extraction and following RT-PCR (Real Time PCR) with primers for Apo A-I mRNA sequence. We have found, that Apo A-I mRNA level decreased in the triton control group to 17\%, but restored up to $89 \%$ in the carmizole group. Carmizole derivate drug works like stimulator of Apo A-I gene expression. That increasing of the expression of antiatherogenic protein gene could me the base of the antiatherogenic effect of the carmizole derivate.

Keywords: azoles; carmizole; atherosclerosis; lipids; triglycerides; LDL; HDL; Apo A-I.

Азолы являются антифунгицидными препаратами. Механизм действия азолов как антифунгицидов связан с блокировкой синтеза стеролов через регуляторы экспрессии. В случае введения азоловых препаратов животным, наблюдался антиатерогенный эффект. В то время, как было показан влияние препаратов группы азолов на уровень липопротеидов в крови и ткани печени, не проводилось исследований по связи действия азолов и экспрессии генов, связанных с липидным обменом. Целью данного исследования является изучение влияния препарата производного кармизола на экспрессию генов интереса - Аполипопротеин А-1 в печени крыс. Для изучения влияния препарата производного кармизола на экспрессию генов использовалась тритоновая модель. Самцов крыс делили на 4 группы: 1) интактный контроль - крысам не вводили препараты, не вводили тритон; 2) активный контроль - крысам вводили тритон, не вводили препарат; 3) группа препарата сравнения - крысам вводили препарат сравнения (фенофибрат), вводили тритон; 4) опытная группа - крысам вводили кармизол, вводили тритон. После определяли уровень экспрессии генов интереса в печени методом RT PCR, а также измеряли состав липидов в сыворотке крови. В результате исследования было установлено, что препарат производного кармизола восстанавливает экспрессию гена Апо А-1 с $17 \%$ (по сравнению с показателями интактного контроля, принятыми за $100 \%$ ) в группе тритонового контроля до $89 \%$ в группе кармизола.

Ключевые слова: азолы; кармизол; атеросклероз; липиды; триглицериды; ЛПВП; ЛНП; Аполипопротеин А-1.

Introduction. Azoles are the main antifungal drug class. The main mechanism of the azoles action is the intercalation in the sterol biosynthesis regulation. Azole derivates interact with the SREBP transcription factor, repressing the sterol biosynthesis [1]. At the same time, the effect of the azole derivates on mammals is antiatherogenic. But there were no publication about connection between azole derivates effect on hyperlipidemia and expression of genes with antiatherogenic effects.

One of such genes, that could be effected by azole derivates, is Apo A-I gene [2].
In our work we used triton model of hyperlipodemia on rats to analyze the effect of carmizole injection on the expression of the main antiatherogenic lipoprotein gene Apo A-I.

Materials and methods. We had four groups of rats: intact control group, triton control group, phenophibrate group and carmizole group. During a seven days we gave a per oral injections of carmizole for the carmizole group, phenophibrate (as a comparison drug) for phenophibrate group and $1 \%$ starch solution for triton control group. On the seven day rats from these groups went 
through intraperitoneal injection of triton WR-1339 $(48.5 \mathrm{mg} / \mathrm{ml})$. On the next day all for groups went through decapitation. Liver tissue samples were taken from each rat. This tissue samples were used for RNA extraction and following RT-PCR (Real Time PCR) with primers for Apo A-I mRNA sequence.

Results. We made Real-Time PCR with rat liver cDNA with primers for Apo A-I mRNA for all experimental groups. We have found, that Apo
A-I mRNA level decreased in the triton control group to $17 \%$, decreased in the phenophibrate group to $12 \%$, but restored up to $89 \%$ in the carmizole group.

Conclusions. Carmizole derivate drug works like stimulator of Apo A-I gene expression. That increasing of the expression of antiatherogenic protein gene could me the base of the antiatherogenic effect of the carmizole derivate.

\section{References}

1. Gsaller F, Hortschansky P, Furukawa T, et al. Sterol Biosynthesis and Azole Tolerance Is Governed by the Opposing Actions of SrbA and the CCAAT Binding Complex. Pathogens. https://doi.org/10.1371/journal. ppat. 1006106 .

2. Fielding CJ, Fielding PE. Molecular physiology of reverse cholesterol transport. Journal of Lipid Research. 1995;36:211-218. 